\title{
Genetic diversity of Angiopolybia pallens (Lepeletier) (Hymenoptera, Vespidae, Polistinae) explained by the disjunction of South American rainforests
}

\author{
A.F. Carvalho ${ }^{1}$, G.M.M. Santos ${ }^{2}$, R.S.T. Menezes ${ }^{1}$ and M.A. Costa ${ }^{1}$ \\ ${ }^{1}$ Departamento de Ciências Biológicas, Universidade Estadual de Santa Cruz, \\ Ilhéus, Bahia, Brasil \\ ${ }^{2}$ Departamento de Ciências Biológicas, \\ Universidade Estadual de Feira de Santana, Feira de Santana, Bahia, Brasil \\ Corresponding author: M.A. Costa \\ E-mail: costama@uesc.br
}

Genet. Mol. Res. 13 (4): 89-94 (2014)

Received March 25, 2013

Accepted November 30, 2013

Published January 8, 2014

DOI http://dx.doi.org/10.4238/2014.January.8.7

\begin{abstract}
Angiopolybia pallens is a swarm-founding wasp that occurs in Atlantic and Amazonian rainforests, which have been isolated from each other by a large arid corridor in central Brazil since the Tertiary. In this study, we used data from polymerase chain reaction-restriction fragment length polymorphism of $16 \mathrm{~S}$ rDNA to infer some aspects of the genetic diversity and evolutionary history of this social wasp population. Samples collected across the species range in both rainforests showed remarkable differences that separated them into two distinct haplogroups. However, some samples from isolated areas in northeastern Bahia were more related to Amazonian lineages than to southern Bahia populations. Vicariant divergenc is discussed under South American rainforests biogeographical proposals.
\end{abstract}

Key words: $16 \mathrm{~S}$ rDNA; South American rainforests; Biogeography; Epiponini; PCR-RFLP; Social wasps 


\section{INTRODUCTION}

The Atlantic and Amazonian rainforests have already been connected (Costa, 2003) but are currently disrupted by an arid corridor, the Brazilian savanna. Such disruption seems to have been caused by cyclic climatic-vegetational changes in the tropical forests during glacial events in the Cenozoic era (Ab'Saber, 1990; Muller and MacDonald, 1995; Mayle et al., 2000; Silva and Bates, 2002; Roig-Juñent et al., 2006). According to Roig-Juñent et al. (2006), the period of higher expansion of the savannas occurred in the upper Cenozoic era, which agrees with a gradual establishment of an arid corridor between Brazilian rainforests during the Tertiary and Quaternary (Costa, 2003).

Several studies using DNA markers have provided information on the lineage diversification during the Quaternary climatic oscillations (Hewitt, 2000, 2004). This approach allowed the identification of genetic profiles and their geographical distribution and has been widely applied for phylogeographical analyses (Carnaval et al., 2009; Resende et al., 2010; Thomé et al., 2010). Polymerase chain reaction-restriction fragment length polymorphism (PCR-RFLP) has successfully provided information on the genetic diversity of bees (Bouga et al., 2005; Brito and Arias, 2005; Collet et al., 2007). However, there is no information on the geographical distribution of mitochondrial lineages of Neotropical social wasps. These analyses could be useful for understanding the historical events affecting the genetic diversity, population structure, and species conservation status.

Social Polistinae is a highly diverse wasp group in the Neotropical region. Studies carried out by Richards (1978) provided initial insights into the phylogeny and geographical distribution of this group. Moreover, Carpenter $(1991,1993)$ reported accurate resolution of the generic relationships within the tribes Polistini, Mischocyttarini, Ropalidiini, and Epiponini. Most of these results were corroborated by Zhu et al. (2000) and Arévalo et al. (2004) using morphological and molecular data. Pickett and Carpenter (2010), however, reviewed several molecular and morphological features of Vespidae and proposed Ropalidiini as the most basal group, followed by Mischocyttarini and the sister tribes Polistini and Epiponini.

Angiopolybia pallens (Lepeletier) is a basal swarm-founding wasp within the tribe Epiponini, restricted to South American rainforests and the Pantanal (Richards, 1978; Silveira, 2002; Silveira et al., 2005; Cruz et al., 2006a,b), with a few populations occurring in fragmented forests in dry biomes. Disjunct Amazonian and Atlantic rainforest populations of these wasps are isolated by thousands of kilometers, and gene flow among them is unlikely to occur.

In this study, we evaluated the genetic divergence among samples of A. pallens collected across the species range by using PCR-RFLP in a 16S rDNA fragment.

\section{MATERIAL AND METHODS}

We analyzed specimens of $A$. pallens collected in the Atlantic $(\mathrm{N}=19)$ and Amazonian $(\mathrm{N}=16)$ rainforests (Table 1). Two individuals of the closely related Angiopolybia paraensis (Spinola) (Andena et al., 2007), whose distribution is restricted to the Amazonian rainforest (Richards, 1978), were included as outgroup.

Total DNA was extracted from the thorax of one individual per nest following the method described in Han and McPheron (1997). 16S rDNA amplifications were conducted using the primers designed by Svenson and Whiting (2004). The PCR consisted of $0.3 \mu \mathrm{L} 5$ 
$\mathrm{U} / \mu \mathrm{L}$ Taq polymerase (Promega), $5 \mu \mathrm{L} 5 \mathrm{X}$ reaction buffer provided by the manufacturer (Promega), $2.5 \mu \mathrm{L} 10 \mathrm{mM}$ dNTPs mix, $3 \mu \mathrm{L} 25 \mathrm{mM} \mathrm{MgCl}_{2}, 2 \mu \mathrm{L}$ DNA, $1.25 \mu \mathrm{L} 20 \mu \mathrm{M}$ of each primer, and sterile water. PCR amplification cycles consisted of an initial heating step for 5 min at $94^{\circ} \mathrm{C}$, followed by 40 cycles of $94^{\circ} \mathrm{C}$ for $1 \mathrm{~min}, 42^{\circ} \mathrm{C}$ for $1.5 \mathrm{~min}$, and $64^{\circ} \mathrm{C}$ for $1.5 \mathrm{~min}$, and an additional 5 min extension step at $64^{\circ} \mathrm{C}$.

Table 1. Sampled localities (L), number of nests (N), haplogroups (H), and geographical designations.

\begin{tabular}{|c|c|c|c|}
\hline Locality (L) & $\mathrm{N}$ & $\mathrm{H}$ & Geographical designation \\
\hline 1 Santa Terezinha & 2 & B & Atlantic rainforest - Northeastern Bahia, Brazil \\
\hline 2 Vera Cruz - Itaparica Island & 2 & B & Atlantic rainforest - Northeastern Bahia, Brazil \\
\hline 3 Ituberá & 2 & $\mathrm{C} ; \mathrm{G}$ & Atlantic rainforest - Northeastern Bahia, Brazil \\
\hline 4 Ilhéus & 6 & A & Atlantic rainforest - Southern Bahia, Brazil \\
\hline 5 Itabuna & 1 & A & Atlantic rainforest - Southern Bahia, Brazil \\
\hline 6 Santa Luzia & 1 & A & Atlantic rainforest - Southern Bahia, Brazil \\
\hline 7 Camacan & 3 & A & Atlantic rainforest - Southern Bahia, Brazil \\
\hline 8 Arataca & 1 & A & Atlantic rainforest - Southern Bahia, Brazil \\
\hline 9 Belmonte & 1 & $\mathrm{E}$ & Atlantic rainforest - Southern Bahia, Brazil \\
\hline 10 Altamira & 5 & $2 \mathrm{C} ; \mathrm{F} ; 2 \mathrm{H}$ & Amazon rainforest - Pará, Brazil \\
\hline 11 Presidente Figueiredo & 5 & $4 \mathrm{C} ; \mathrm{D}$ & Amazon rainforest - Amazonas, Brazil \\
\hline 12 Iquitos & 1 & $\mathrm{C}$ & Amazon rainforest - Maynas, Loreto, Peru \\
\hline 13 Napo & 1 & $\mathrm{C}$ & Amazon rainforest - Ecuador \\
\hline 14 Paracou & 1 & $\mathrm{C}$ & Amazon rainforest - French Guiana \\
\hline 15 Petit Saut & 2 & $\mathrm{C}$ & Amazon rainforest - French Guiana \\
\hline 16 Maripasoula & 1 & $\mathrm{C}$ & Amazon rainforest - French Guiana \\
\hline
\end{tabular}

The amplified 16S rDNA fragment was digested with 14 restriction endonucleases (AluI, BamHI, BglII, ClaI, DraI, EcoRV, HaeIII, HincII, HphI, MboI, PstI, SspI, TaqI, and $V s p \mathrm{I})$, one at a time. The digested fragments were separated by electrophoresis on $2.0 \%$ agarose gels in $0.5 \mathrm{X}$ TBE buffer, stained with ethidium bromide, and visualized and photographed under UV light. We used $0.5 \mu \mathrm{g} / \mu \mathrm{L} \Phi \mathrm{X} 174 \mathrm{DNA} /$ BsuRI (HaeIII) as a size marker (Fermentas).

\section{RESULTS AND DISCUSSION}

A. pallens showed restriction fragment length polymorphism for the four enzymes, DraI, PstI, $S s p \mathrm{I}$, and $V_{s p \mathrm{I}}$, in the $16 \mathrm{~S}$ rDNA fragment ( $\left.\sim 580 \mathrm{bp}\right)$. The restriction fragment estimated sizes are shown in Table 2. The PCR-RFLP patterns allowed us to separate the $A$. pallens samples into eight distinct haplogroups (Tables 1 and 3; Figure 1).

Table 2. Restriction fragment size estimates (in base pairs) of all fragment patterns for the16S rDNA gene fragment.

\begin{tabular}{|c|c|c|c|c|c|c|c|c|c|c|c|c|c|c|c|c|}
\hline \multicolumn{17}{|c|}{$16 \mathrm{~S}$ rDNA } \\
\hline & & \multicolumn{3}{|c|}{ SspI } & \multicolumn{2}{|r|}{ Pst $\mathrm{I}$} & \multicolumn{6}{|c|}{$V s p \mathrm{I}$} & \multicolumn{4}{|c|}{ DraI } \\
\hline 580 & - & & & & 580 & - & 580 & - & & & & 260 & & & - & - \\
\hline 300 & & & - & & 490 & - & 400 & & & - & & 220 & & & & - \\
\hline 250 & & —* & & & & & 300 & & & & - & 210 & & — & & \\
\hline 280 & & & - & —* & & & 200 & & —* & & & 200 & —* & & & \\
\hline 80 & & - & & & 90 & - & 180 & & - & - & - & 180 & - & & & \\
\hline 20 & & & & - & & & 100 & & & & - & 160 & & - & —* & \\
\hline & & & & & & & & & & & & 100 & & & & - \\
\hline
\end{tabular}

*Two overlapping bands. 
Table 3. Designation of the haplotypes found after digestion with enzymes $S s p \mathrm{I}$, PstI, VspI, and DraI and distribution of such as haplotypes in the eight haplogroups of A. pallens.

\begin{tabular}{|c|c|c|c|c|c|c|c|c|}
\hline Haplogroup/enzyme & A & $\mathrm{B}$ & $\mathrm{C}$ & $\mathrm{D}$ & $\mathrm{E}$ & $\mathrm{F}$ & G & $\mathrm{H}$ \\
\hline \multirow[t]{3}{*}{ Ssp I } & 250 & & & & 250 & 580 & 280 & 580 \\
\hline & 250 & 300 & 300 & 580 & 250 & & 280 & \\
\hline & 80 & 280 & 280 & & 80 & & 20 & \\
\hline \multirow[t]{2}{*}{ Pst $\mathrm{I}$} & 490 & 490 & 490 & 580 & 490 & 490 & 490 & 490 \\
\hline & 90 & 90 & 90 & & 90 & 90 & 90 & 90 \\
\hline \multirow[t]{3}{*}{ Vsp I } & 200 & 400 & 200 & 300 & 200 & 200 & 200 & 200 \\
\hline & 200 & 180 & 200 & 190 & 200 & 200 & 200 & 200 \\
\hline & 180 & & 180 & 90 & 180 & 180 & 180 & 180 \\
\hline \multirow[t]{3}{*}{ DraI } & 210 & 210 & 210 & 260 & 200 & 260 & 210 & 210 \\
\hline & 210 & 210 & 210 & 160 & 200 & 220 & 210 & 210 \\
\hline & 160 & 160 & 160 & 160 & 180 & 100 & 160 & 160 \\
\hline
\end{tabular}

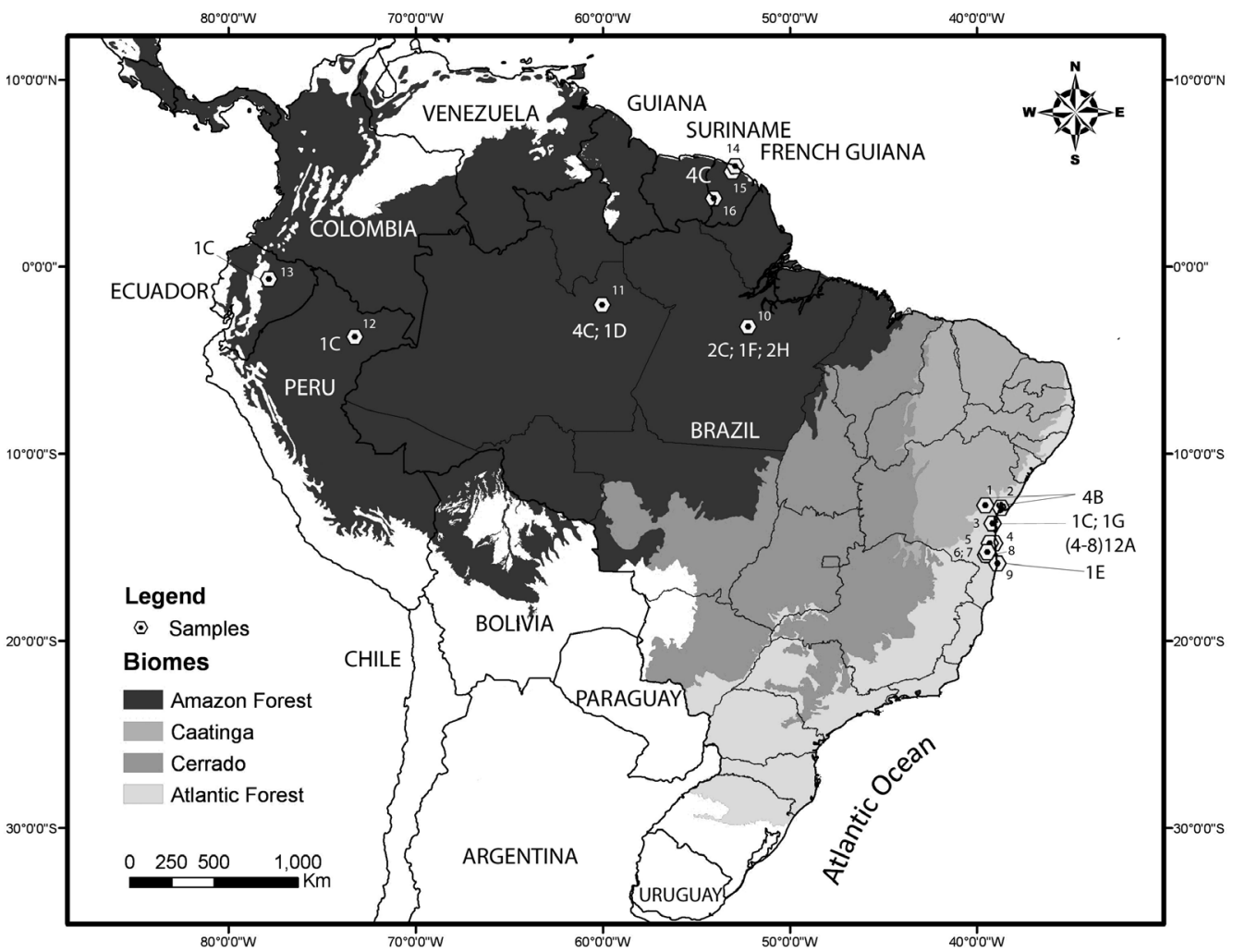

Figure 1. Haplogroup distribution of populations of Angiopolybia pallens in South America. Hexagons refer to the sampled sites. The numbers refer to the sampling locality codes shown in Table 1 . Numbers followed by a letter represent the number of nests sampled and the haplogroup code $(\mathrm{A}-\mathrm{H})$, respectively.

Samples from southern Bahia were placed in haplogroup A. Samples from Santa Terezinha (L1) and Vera Cruz (L2), both in northeastern Bahia, were combined into haplogroup B, and samples from French Guiana, Ecuador, and Peru were grouped into haplogroup C. In 
the latter were also included two samples from the state of Pará (L10), four from the state of Amazonas (L11), and one from northeastern Bahia (L3, in Ituberá, Bahia). In the other five haplogroups, samples with rare haplotype combinations were included. A. paraensis had a haplotype combination similar to those in haplogroup $\mathrm{C}$, and therefore this species was included in this group. Haplogroup $\mathrm{C}$ was the most frequent and widely distributed in the Amazonian region, whereas the Atlantic rainforest was mostly represented by haplogroup A.

The presence of $A$. pallens in both the Amazonian and Atlantic forests suggests that this species had an ample and continuous range in the past, which is also consistent with the hypothesis of the existence of a Cenozoic connection between these forests before glacial events (Costa, 2003). The great expansion of the Brazilian savannas on the upper Cenozoic (Roig-Juñent et al., 2006) could have helped to establish the current disjunct distribution. A similar disjunct distribution has been observed for other Polistinae species such as Epipona media Cooper (Menezes et al., 2010) and Synoeca septentrionalis (Menezes et al., 2011), but so far, there are no published studies that specifically address this issue.

The ample occurrence of haplogroup $\mathrm{C}$ in the Amazonian region and in northeastern Brazil (L3 in Ituberá) suggests that this haplogroup could be related to the putative ancestral lineage of $A$. pallens and that the colonization might have followed a north to northeast route. Under these assumptions, the center of origin of $A$. pallens would probably be in the Amazonian region.

A more extended analysis within a phylogeographical framework is under development in order to test if Polistinae species ecologically dependent on humid environments, such as A. pallens, might have had their populations disrupted after the expansion of the savannas across rainforests in the Cenozoic era, and if forest refuges have represented places of species diversification. Such investigations, allied to inferences on the biogeographical factors causing variation on the Neotropical Polistinae, will provide the required information to answer some of the questions raised here.

\section{ACKNOWLEDGMENTS}

We are grateful to James M. Carpenter (American Museum of Natural History, USA), Orlando T. Silveira and José Nazareno (Museu Paraense Emílio Goeldi, Brazil), and Fernando B. Noll and Getúlio Tanaka (Universidade Estadual Paulista, Brazil) for providing some of the samples included in this work. We also thank Sergio R. Andena (Universidade Estadual de Feira de Santana, Brazil) for the specimens identification; Lúcio A.O. Campos (Universidade Federal de Viçosa, Brazil), Fernanda A. Gaiotto and Janisete G. Silva (Universidade Estadual de Santa Cruz, Brazil), and Marco A. Del Lama (Universidade Federal de São Carlos, Brazil) for their comments on an earlier version of this manuscript; and Iuri R. Dias (Universidade Estadual de Santa Cruz, Brazil) for helping with the map preparation. Study supported by Fundação de Amparo à Pesquisa do Estado da Bahia (FAPESB), and Coordenação de Aperfeiçoamento de Pessoal de Nível Superior (CAPES).

\section{REFERENCES}

Ab’Saber AN (1990). Paleoclimas quaternários e pré-história da América Tropical I. Ver. Bras. Biol. 50: 805-820.

Andena SR, Noll FB and Carpenter JM (2007). Phylogenetic analysis of the Neotropical social wasps of the genus Angiopolybia Araujo, 1946 (Hymenoptera, Vespidae, Epiponini). Zootaxa 1427: 57-64.

Arévalo E, Zhu Y, Carpenter JM and et al (2004). The phylogeny of the social wasp subfamily Polistinae: evidence from 
microsatellite flanking sequences, mitochondrial COI sequence, and morphological characters. BMC Evol. Biol. 4: 8-16. Bouga M, Harizanis PC, Kilias G and Alahiotis S (2005). Genetic divergence and phylogenetic relationships of honey bee Apis mellifera (Hymenoptera: Apidae) populations from Greece and Cyprus using PCR-RFLP analysis of three mtDNA segments. Apidologie 36: 335-344.

Brito RM and Arias MC (2005). Mitochondrial DNA characterization of two Partamona species (Hymenoptera, Apidae, Meliponini) by PCR+RFLP and sequencing. Apidologie 36: 431-437.

Carnaval AC, Hickerson MJ, Haddad CF, Rodrigues MT, et al. (2009). Stability predicts genetic diversity in the Brazilian Atlantic forest hotspot. Science 323: 785-789.

Carpenter JM (1991). Phylogenetic Relationships and the Origin of Social Behavior in the Vespidae. In: The Social Biology of Wasps (Ross KG and Matthews RW, eds.). Cornell University Press, Ithaca, 7-32.

Carpenter JM (1993). Biogeographic Patterns in the Vespidae (Hymenoptera), Two Views of Africa and South America. In: Biological Relationships Between Africa and South America (Goldblatt P, ed.). Yale University Press, New Haven, 139-155.

Collet T, Arias MC and Del Lama MA (2007). 16S mtDNA variation in Apis mellifera detected by PCR-RFLP. Apidologie 38: $47-54$.

Costa LP (2003). The historical bridge between the Amazon and the Atlantic Forest of Brazil: a study of molecular phylogeography with small mammals. J. Biogeogr. 30: 71-86.

Cruz JD, Giannotti E, Santos GMM, Bichara CC, et al. (2006a). Daily activity resources collection by the swarm-founding wasps Angiopolybia pallens (Lepeletier, 1836) (Hymenoptera: Vespidae). Sociobiology 47: 829-842.

Cruz JD, Giannotti E, Santos GMM, Bichara CC, et al. (2006b). Nest site selection and flying capacity of Neotropical wasp Angiopolybia pallens (Lepeletier, 1836) (Hymenoptera: Vespidae) in Atlantic Rain Forest, Bahia State, Brasil. Sociobiology 47: 739-749.

Han HY and McPheron BA (1997). Molecular phylogenetic study of Tephritidae (Insecta: Diptera) using partial sequences of the mitochondrial 16S ribosomal DNA. Mol. Phylogenet. Evol. 7: 17-32.

Hewitt G (2000). The genetic legacy of the Quaternary ice ages. Nature 405: 907-913.

Hewitt GM (2004). Genetic consequences of climatic oscillations in the Quaternary. Philos. Trans. R. Soc. Lond. B Biol. Sci. 359: 183-195.

Mayle FE, Burbridge R and Killeen TJ (2000). Millennial-scale dynamics of southern Amazonian rain forests. Science 290: 2291-2294.

Menezes RST, Carvalho AF, Raw A and Costa MA (2010). Epipona media Cooper (Hymenoptera: Vespidae), a social wasp new to the Brazilian Atlantic Forest. Neotrop. Entomol. 39: 1046-1047.

Menezes RS, Andena SR, Carvalho AF and Costa MA (2011). First records of Synoeca septentrionalis Richards, 1978 (Hymenoptera, Vespidae, Epiponini) in the Brazilian Atlantic Rain Forest. Zookeys 75-78.

Muller RA and MacDonald GJ (1995). Glacial cycles and orbital inclination. Nature 377: 107-108.

Pickett KM and Carpenter JM (2010). Simultaneous analysis and the origin of eusociality in the Vespidae (Insecta: Hymenoptera). Arthropod Syst. Phylogeny 68: 3-33.

Resende HC, Yotoko KSC, DeLabie JHC, Costa MA, et al. (2010). Pliocene and Pleistocene events shaping the genetic diversity within the central corridor of the Brazilian Atlantic Forest. Biol. J. Linn. Soc. 101: 949-960.

Richards OW (1978). The Social Wasps of the Americas Excluding the Vespinae. British Museum Natural History, London.

Roig-Juñent S, Domínguez MC, Flores GE and Matton C (2006). Biogeographic history of South American arid lands: a view from its arthropods using TASS analysis. J. Arid Environ. 66: 404-420.

Silva JMC and Bates JM (2002). Biogeographic patterns and conservation in the South American Cerrado: a tropical savanna hotspot. BioScience 52: 225-233.

Silveira OT (2002). Surveying neotropical social wasps. An evaluation of methods in the "Ferreira Penna" research station (ECFPN), in Caxiuanã, PA, Brazil (Hym., Vespidae, Polistinae). Pap. Avulsos Zool. 42: 299-323.

Silveira OT, Esposito MC and Santos-Jr JN (2005). Social wasps and bees captured in carrion traps in a rainforest in Brazil. Entomol. Sci. 8: 33-39.

Svenson GJ and Whiting MF (2004). Phylogeny of Mantodea based on molecular data: evolution of a charismatic predator. Syst. Entomol. 29: 359-370.

Thomé MT, Zamudio KR, Giovanelli JG, Haddad CF, et al. (2010). Phylogeography of endemic toads and post-Pliocene persistence of the Brazilian Atlantic Forest. Mol. Phylogenet. Evol. 55: 1018-1031.

Zhu Y, Queller DC and Strassmann JE (2000). A phylogenetic perspective on sequence evolution in microsatellite loci. J. Mol. Evol. 50: 324-338. 